\title{
Development of Animation-Based Fairy Tales Learning Model for Elementary School Students
}

\author{
Sunarti ${ }^{1}$, Selly Rahmawati ${ }^{2}$, SetiaWardani ${ }^{3}$ \\ ${ }^{1}$ Postgraduate Departement; ${ }^{2}$ Elementary school Teacher Education Departement; ${ }^{3}$ Information Technology Departement, \\ Universitas PGRI Yogyakarta \\ Jl. PGRI I Sonosewu No. 117 Yogyakarta 55182 Telp. (0274) 376808, Fax. (2740) 376808 \\ ${ }^{1}$ Email: bunartisadja@gmail.com
}

\begin{abstract}
Sunarti, Rahmawati S, Wardani S. 2017. Development of Animation-Based Fairy Tales Learning Model for Elementary School Students. Proc Internat Conf Sci Engin 1: 239-243. The purpose of this research is developing an animation-based fairy tale as a teaching model for elementary students.In addition, this study is also intended to determine the effectiveness of animation-based fairy tale as a teaching model. This research type is research of development with subject is elementary students in SD Sonosewu. Methods of data collection used observation, questionnaires and tests. The data analysis technique to be used is quantitative approach with t-test independent sample. Output targets to be generated in the study are: (1) Design of animation-based fairy tales for elementary students developed with 6 steps of research and development i.e. research and gathering, planning, product draft development, initial field trials, revising test results and field trials. (2) An animation-based fairy tale model is effective in improving Civics achievement and Indonesian achievement.
\end{abstract}

Keywords: Learning Model, Tale, Animation

\section{INTRODUCTION}

Fairy tale is a simple imagination story which functions as delivering moral value (education) and amusement. Fairy tale spread heredity and consider as most important in moral value in the story based on the condition of an area. There is a delineation of people authenticity which reflects their behavior and culture of a society. (AgusTriyanto, 2007).

Fairy tale generally is shown through media as books, television, CD, and DVD. Other ways of presentation can be in a theater, drama, and opera. It is also done by reading, listening and watching. By watching, people will observe the roles clearly and attractively. By performance, fairy tale possesses value that it could be received by audience because the characters are moving. It is also with music.

But in this modern IT development, fairy tale is forgotten. Many children do not know it. They prefer watching film and playing games in the cell phone and computer. Whereas Joseph Frank as cited by Asfandiyar (2007) mentions that fairy tale can be an effective method in developing cognitive, affective, and conative aspects of children. The model of story-telling in the schools generally was done by reading from the story books, using illustration and books, using flannel board, using dolls, using finger dolls (Nurlaily, 2010). Those models were not interesting to children as the development of children attention to IT.
Animation media enrich students' experience and competition through the learning material. Agina (in Rahmatullah, 2013) explains that the use of animation in learning may improve quality and learningoutput. It has the same as the research of Yosi Rotbain, Gili MarbachAd and Ruth Stavy titled Using Computer Animation To Teach High School Molecular Biologyshows that computer animation in leaning biology can improve learning achievement. Various models of animationbased learning prove to improve students' achievement. Finally, as those explanations, the animation-based fairy tale is needed to develop to continue fairy tale and improve students' achievement.

\section{MATERIALS AND METHODS}

\section{Study area}

The study was conducted in Yogyakarta area. The experiment of the fairy tale animation-based learning was done in SD Sonosewu Yogyakarta. The object of the study was the model of fairy tale animation-based. The subject of the study were the students of grades $3 \mathrm{a}$ and $3 b$ in SD Sonosewu.

\section{Procedures}

Model of development used Research and Development (R\&D). Borg and Gall (2003) mention 10 steps in research and development study; those are as mentioned in the table. But this study used only step 1 to 6 , because of the limited time. 


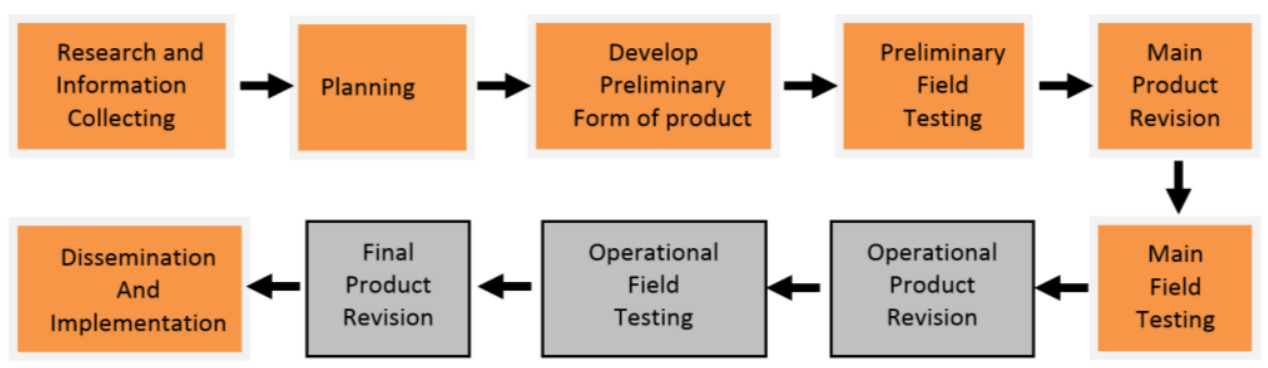

Figure 1. Research stages R\&D.

\section{Data Analysis}

To know the effectiveness of the learning using animation-based fairy tale, the analyzed data is inferential statistical analysis technic with t-test independent sample.

\section{RESULTS AND DISCUSSION}

\section{Development of Animation-Based Fairy Tale Learning Model}

Development of animation-based fairy tale leaning model was conducted in 7 steps, they were Research and Information collecting, Planning, Develop Preliminary Form of product, Preliminary Field testing, Main product revision, Main field testing, and Disseminationand implementation. In the research and information collecting, based on the result of the interview, it was known students' knowledge about the fairy tale was very lack and teacher has not implement the animation-based fairy tale learning in the classroom.

In the planning step, thematic learning model was chosen to develop animation-based fairy tale learning.
Based on Depdiknas (Trianto, 2011) thematic learning as learning model is one of the integrated learning models. The term of thematic learning is an integrated learning which uses theme for correlates some subjects so that can give meaningful experience for students. In the step of Develop Preliminary Form of Product, there were five steps as seen below.

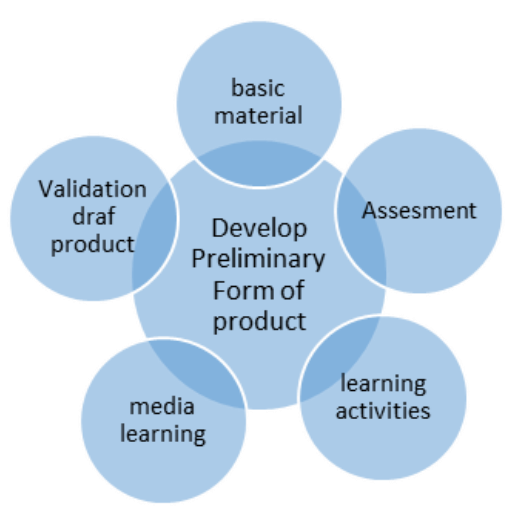

Figure 2. Develop preliminary form of product steps.

Table 1. Syntax of Thematic Learning Animation-Based Fairy Tale.

\begin{tabular}{ll}
\hline Steps & Teacher's Behavior \\
\hline Fase-1 & 1. Correlating recent material and past material \\
Introduction & 2. Motivating students \\
& 3. Giving questions to students to know requirement concepts which are got by \\
& students. \\
& 5. Explaining learning theme \\
& Presentation of concepts required by student through animation-based fairy tale \\
Fase-2 & 1. Distributing the book and evaluation sheet \\
Material Presentation & 2. Asking student to do the evaluation sheet \\
Fase-3 & 3. Giving guidance as needed. \\
Guiding Training & 1. Asking student to read the answer of the evaluation \\
& 2. Confirming the student's answer \\
Fase-4 & 3. Giving feed back to the student's answer \\
Comprehension and feed back & 4. Giving reflection to the student's answer. \\
& 1. Guiding students to conclude the learning material \\
Fase-5 & 2. Giving homework \\
Evolving by giving chance to follow up & \\
training and implementation & Teacher helps students to reflect or evaluate the result of the task. \\
Fase-6 &
\end{tabular}

(Development Result from: Trianto, 2010). 
Basic Material which was chosen by the researcher was the material of Yogyakarta fairy tales. In Yogyakarta, there are two fairy tales which are known, CandiSewu (RoroJonggrang) and Kali Gajah Wong. Assessment used in this study was Indonesian language evaluation and moral value (PKn) evaluation. Concept of Learning Activity of animation-based fairy tale learning model can be seen in the table above (table 1).

This model of animation-based fairy tale focused on the second step. It consists of some steps, as the following.
1. Students pay attention to the media of animationbased fairy tale which are Kali Gajah Wong and Candi Sewu tales.

2. Students tell the story orally by their own sentences in front of the other students.

3. Students conclude the messages content in the stories and mention the moral values form those two tales.

Learning media animation-based is a supporting system from the learning model. The design of the media is shown in the following table.

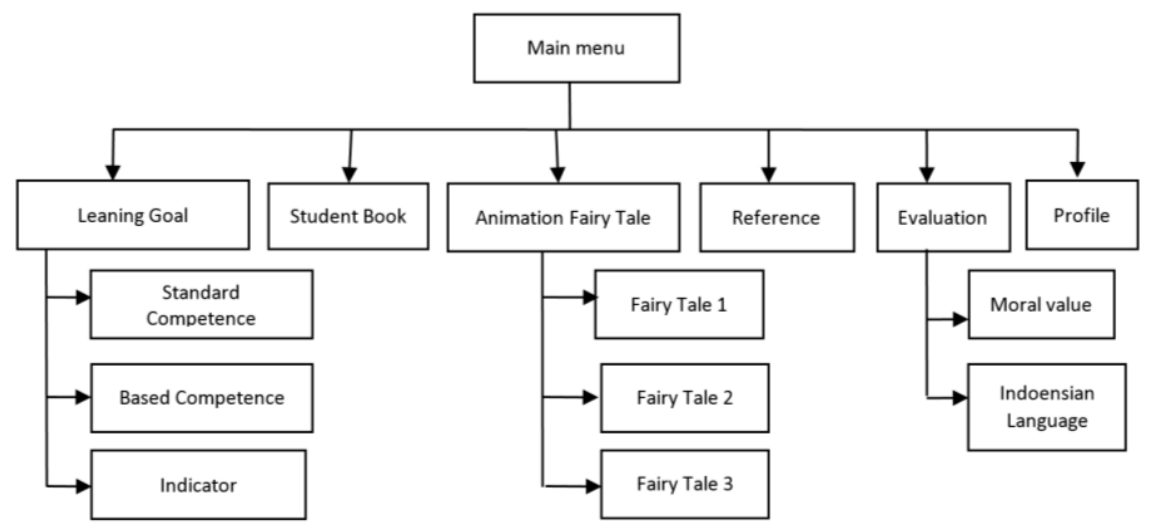

Figure 3. The design of the media.

Validation draft product was conducted by the learning model expert, IT expert, oral value material expert, and Indonesian Language material expert.Based on the result, it can be concluded that learning media for animation-based fairy tale learning model was included in good criterion.

In the Preliminary Field Testing, it was conducted by 5 students of grades $3 \mathrm{a}$ and $3 \mathrm{~b}$ in SD Sonosewu. Based on the questionnaire of student response and teacher response, it was known that quality of learning model animation-based fairy tale was included as good criterion.

In the main product revision step, design revision was done as the result of the assessment and the input from the expert judgment.

In the main field testing, it was known the data description for control class and experiment class are as shown the following.

Table 2. Data Description.

\begin{tabular}{|c|c|c|c|c|c|c|c|c|}
\hline & \multicolumn{4}{|c|}{ Control class } & \multicolumn{4}{|c|}{ Experimental class } \\
\hline & Min Score & Max Score & Mean & SD & Min Score & Max Score & Mean & SD \\
\hline PrestasiPKn & 65 & 83 & 73.78 & 4.671 & 75 & 90 & 81.59 & 4.787 \\
\hline PrestasiBahasa Indonesia & 60 & 70 & 65.39 & 3.201 & 66 & 85 & 75.77 & 5.571 \\
\hline
\end{tabular}

\section{The Effectiveness of Animation-Based Fairy Tale Learning Model}

Table 3. Data Description the achievement significant score.

\begin{tabular}{llll}
\hline Aspect & T score & Significant score & Explanation \\
\hline Moral value achievement & -5.538 & 0,000 & significant difference \\
Indonesian Language achievement & -7.707 & 0,000 & significant difference \\
\hline
\end{tabular}


Based on the t-test, it can be seen that the achievement significant score of moral value and Indonesian language subject is lower than 0,05 , so that $\mathrm{Ho}$ is rejected and $\mathrm{Ha}$ is received. It shows that there is significant difference achievement of moral value and Indonesian language who use the animation-based fairy tale learning model and explanation. The negative score shows that the achievement of moral value and Indonesian language using animation-based is better that them using explanation learning model. It can be concluded that learning model of animation-based fairy tale is effective to improve moral value and Indonesian language achievements.

\section{Discussion}

Based on the result of the study, it can be known that the learning achievement of moral value and Indonesian language using animation-based fairy tale learning model is more effective that using explanation learning model. According to Smiyati and Asra (2011), learning by using story telling method is very needed for students who step into end of kindergarten year, and 6-12 year old students. It is because they can think logically and critically.

Joseph Frank as cited by Asfandiyar (2007) says that fairy tale can be an effective method to develop cognitive, affective, social and conative aspects of children. It is in accordance with the research conducted by Satinem and Achmad (2015) who said that the learning process folkloreusing a thematic approach is applied to the third grade elementary school studentsproved effective because process of integrative folk lore learning is given by integrating four components of language skills; listening, speaking, reading, and writing, into activities based on the chosen theme; can create fun learning and not boring situation.

Burns (2001) mentions that story telling functions as strategy in growing positive attitude to children. Fairy tale or story also functions as entertaining, educating, forcing emotion, imagination and creativity, and improving language competence, as well as adding language vocabularies to students. Fairy tale can create a space of thought that children become critical and smart.

Besides, Collin (in Nur, 2010) says that fairy tale prepares conceptual framework to think which allows children form whole experience they acquire. Fairy tale causes children map experience mentally and see an image in their head. It is supported by Itadz (2008), who explains that there are some point of view of fairy tale functions. Those are to help self-figure and children morality, force children's verbal skill, motivate children to write, open childrens' knowledge.

Based on the theory of Gastalt learning (Rusman, 2012), object or specific event will be viewed as a whole organized thing. Meaning of an object/event is in the whole form and not in the part of it. Learning will be more meaningful if the material is given intact. It shows that for achieving learning goal must notice the whole structures and components of the learning process. The developed fairy tale thematic learning in this study conducts a whole learning that children can comprehend the meaning of the material.

Besides, this learning model is supported by animation. Based on theory of Neo in Munir (2008), the benefits of animation are:

a. Bringing information in one basis form which is performed.

b. Giving the emphasis because changing and moving information can attract audience attention to see and motivate them to act.

c. Preserving a visual connection and attract audience attention unconsciously from the prepared theme.

d. Students will learn fast and possess good attitude.

e. Flexible, practical, consistent, and attractive.

According to Harrison and Hummell in Rahmatullah (2013) state that animation-based media enrich experience and students' competence in various subject. The use of animation in learning activity can improve quality of process and result of learning.

Those some theories explain that the thematic learning model implemented result whole learning so that students can catch the meaning of the learning or subject. Fairy tale learning model can improve achievement because growing positive attitude to learning process, serving a conceptual framework to think, mapping experience mentally and seeing image, as well as open children's knowledge. Learning model which is completed with animation can also make information clearer and emphasize the important information so students deeply comprehend the subject. Then, the animation-based fairy tale learning model is interesting to students so that can improve students' comprehension.

\section{CONCLUSIONS}

The result of the research showed that animation-based fairy tale learning model improves process of learning and student's leaning achievement.

\section{ACKNOWLEDGEMENTS}

The writers express deep thanks to Universitas PGRI Yogyakarta especially LPPM UPY, school principal, teachers and students of SD Sonosewu, students of UPY who help in completing the study, as well as the editor and reviewer who load the result of this study.

\section{REFERENCES}

Asfandiyar, Andi Yudha. 2007. Cara Pintar Mendongeng, Mizan, Jakarta.

Borg, W. R. \& Gall, M. D. 2003. Educational Research: an Introduction ( $7^{\text {th }}$ Ed.). New York: Longman, Inc.

Burns, G.W. 2001. 101 Healing Stories: Using Methapors in Therapy. New York: John Willey \& Sons.

Itadz. 2008. Cerita Untuk Anak Usia Dini. Tiara Wacana, Yogyakarta. 
Muhammad Rahmattullah. 2013. Pengaruh Pemanfaatan Media Pembelajaran Film Animasi terhadap Hasil Belajar. h 178186, http://ejournal.unesa.ac.id/article/4272/19/article.pdf

Munir. 2008. Multimedia: Konsep \& Aplikasi dalam Pendidikan. Alfabeta, Bandung.

Nur, Latifah. 2010. Metode Mendongeng Dalam Meningkatkan Perkembangan Kecerdasan Moral Anak Usia Prasekolah. Universitas Muria Kudus, Kudus.

Nurlaily, Fadillah 2010. Pengaruh metode bercerita menggunakan buku cerita bergambar terhadap keterampilan berbicar aanak usia dini. (Skipsi). UPI, Bandung. (Indonesia)

Rusman 2013. Model-Model Pembelajaran. Rajawali Pers, Jakarta.

Satinem danAchmad. 2015. Teaching Materials Model Folklore in Learning Indonesian Base on Thematik Approach.
International Journal of Language Education and Culture review, Vol. 1 (2) p 27-34 http://pps.unj.ac.id

SumiatidanAsra. 2011. MetodePembelajaran. Wacana Prima, Bandung.

Trianto. 2010. Mendesain Model Pembelajaran Inovatif-Progresif. Kencana, Jakarta.

Triyanto, Agus. 2007. PembahasanTuntas Kompetesi Bahasa Indonesia untuk SMP dan MTs kelas VII. Esis, Jakarta

Yosi Rotbain, Gili Marbach-Ad dan Ruth Stavy, Using a Computer Animation To Teach High School Molecular Biology. J Sci Educ Technol, Vol. 17, 2008, h. 49-58, http://link.springer.com/article/10.1007/s10956-007-90804?no-access=true 
THIS PAGE INTENTIONALLY LEFT BLANK 